\title{
Night Shift Work Accelerates Menopausal Age in Health Workers
}

\author{
Sri Ratna Dwiningsih ${ }^{1 *}$, Samsulhadi ${ }^{1}$, Arif Tunjungseto ${ }^{1}$, Monika $^{2}$, Arsana Wiyasa $^{3}$ \\ ${ }^{1}$ Division of Endocrinology and Reproductive Fertility, Department of Obstetrics and Gynecology, Faculty of Medicine, \\ Universitas Airlangga - Dr. Soetomo General Academic Hospital, Surabaya, Indonesia \\ ${ }^{2}$ Department of Obstetrics and Gynecology, Faculty of Medicine, Universitas Airlangga - Dr. Soetomo General Academic \\ Hospital, Surabaya, Indonesia \\ ${ }^{3}$ Division of Endocrinology and Reproductive Fertility, Department of Obstetrics \& Gynecology, Faculty of Medicine, \\ Brawijaya University - Dr. Saiful Anwar General Hospital, Malang, Indonesia
}

\section{A R T I C L E I N F O}

\section{Article history:}

Received 09 March 2021

Received in revised form 28 May

2019

Accepted 15 June 2021

Available online 30 June 2021

Keywords:

Menopause,

Night shift,

Social determinants of health.

*) Corresponding author:

sri-r-d@fk.unair.ac.id

\begin{abstract}
A B S T RA C T
Introduction: Earlier menopause has been associated with increased risk of cardiovascular disease, osteoporosis, shorter life expectancy and even cognitive decline. There are many factors that cause differences in the age of menopause in women, one of these environmental factors is a history of night shift work as a consequence of a job. It is not yet known whether female medical workers, with a history of night shifts, get earlier menopause.

Methods: This case control study was conducted among 57 female night workers of the Dr. Soetomo General Academic Hospital. Data collection was conducted from December 2019 - March 2020. The study sample was postmenopausal health workers (nurse and midwife) and administrators. The instrument used in this study was a list of interview questions. The data was processed using SPSS software release 23 .

Results: The results show that from 45 children diagnosed with ALL, $53 \%$ are of the age $\leq 5$ years old, with $58 \%$ males and $42 \%$ females. $13 \%$ of the patients are in the high risk group and $87 \%$ are in the standard risk group. Nutritional statuses of patients are $2 \%$ of them obese experienced remission after induction phase therapy, $56 \%$ normal with $80 \%$ of them experienced remission. $40 \%$ underweight with $89 \%$ of them experienced remission and $11 \%$ not experienced remission, $2 \%$ malnutrition and experienced remission. There is no correlation between the nutritional status of children with acute lymphoblastic leukemia with the outcome of induction phase $(p=0.798)$. Conclusion: In conclusion, there is no correlation between nutritional status and remission outcome of patients with ALL in the induction phase of therapy. However, high percentage of underweight patients shows nutrition needs special attention to improve therapy outcomes.
\end{abstract}

\section{Introduction}

Menopause is a phase that is experienced physiologically by a woman, where she will experience various changes, both physically and psychologically. Along with increasing age, there are many processes of development and growth that occur in humans. These changes are found mostly in women, because the aging process occurs prominently during the menopause phase. Menopause is not a sudden event but a cumulative result of long previous events, starting from fetus, puberty, pregnancy, and menopause. ${ }^{1-3}$ Menopause occures when a minimum number of oocytes cease to be viable, the variation in timing of which is dependent on rates follicle atresia. Estrogen level decrease during menopause cause some symptoms of menopause.

The average age of menopause is 50.5 years in Indonesian women and 51.1 years in Asian women in general. About
1 percent of women begin menopause before 40 years old, which is called premature menopause or primary ovarian insufficiency. About 5 percent of women undergo menopause between ages 40 and 45 . This is referred to as early menopause. Earlier menopause has been associated with increased risk of cardiovascular disease, osteoporosis, shorter life expectancy and even cognitive decline. ${ }^{4,5}$

There are many factors that affect the difference in menopausal age between one woman to others. Generally, the factors that can affect a woman's menopausal age can be divided into genetic and environmental factors. ${ }^{4,5}$ Desynchronization from environmental circadian cues, as experienced by night workers, may impact menopausal timing through chronic dysregulation of gonadal function. Exposure to artificial light during dark hours suppresses and alters the timing of nocturnal pineal melatonin secretion. Observations that endogenous melatonin decrease during puberty correlate with functional 
hypogonadism or that circulating melatonin has been inversely correlated with estrogen levels in amenorrhoeic women could suggest inhibitory effect of melatonin on ovary function. ${ }^{6}$

This study will discuss one of the factors that influence menopausal age from the environmental factor, which is the history of night shift work as a consequence of working as a medical workers.

\section{Methods}

This is an analytic research with a case control study design and was conducted at Dr. Soetomo General Academic Hospital, Surabaya. The population of this study were menopausal women with or without night shift work history at Dr. Soetomo General Academic Hospital, Surabaya, with the inclusion criteria of workers who had natural menopause and the exclusion criteria were workers who had menopause with history of ovarian surgery, chemotherapy or radiation, or autoimmune diseases. Participants, who was involved in this study, were those who worked as nurses, midwives and administrative officers at Dr. Soetomo General Academic Hospital, Surabaya.

The data was collected by using primary data from interviews conducted from December 2019 to March 2020. The instrument used in this study was a list of interview questions. The sample size was calculated using the mean difference formula:

$$
\begin{aligned}
n_{1}=n_{2}=2\left[\left(\frac{\left.Z_{\alpha}+Z_{\beta}\right) s}{X_{1}-X_{2}}\right]^{2}\right. & =2\left[\frac{(1.96+0.842) 2.7}{2}\right]^{2} \\
& =28.57 \sim 29
\end{aligned}
$$

There were 57 participants, $28(49.12 \%)$ of which had history of night shift work and $29(50.88 \%)$ without history of night shift work. Independent variable in this study is the night shift work and the dependent variable is the age of menopause.

The collected data were processed using SPSS Statistics 23 software and presented in tabular and narrative form. To find out whether the research sample had a normal or abnormal distribution type, the Kolmogorov-Smirnov Goodness of Fit Test was used and it was found that the data with several parameters to be tested had a p-value $>0.05$, which showed a normal data distribution. Thus, further testing was carried out using the independent t-test. The variable in this study used a numerical scale, namely the age of menopause. Tests were carried out using SPSS Statistics 23 software.

\section{Research Flow}

Tracing and recording of Dr. Soetomo General Academic Hospital workers was conducted in Obstetrics and Gynecology ward, Obstetrics and Gynecology outpatient department and administration office. Workers who had menopause were included in the inclusion criteria. Interviews were conducted in workers who were qualified the list of inclusion and exclusion criteria. Then data processing and tabulation was carried out. Data is presented in tabular and narrative form (Figure 1).

Participants were given questions about their social, health, obstetric and gynecological history, which would be used as data on the characteristics of the study participants. History of work was also part of the questions list.

Our main outcome are to explore that night shift work have correlation with menopausal age and whether night shift work make menopause earlier.
Acording to WHO menopause defined as permanent cessation of menstruation resulting from loss of ovarian follicular activity. Night shift work at Dr. Soetomo General Academic Hospital defined if they had night shift work rotation at least twice a week. from $9 \mathrm{pm}$ to $7 \mathrm{am}$.

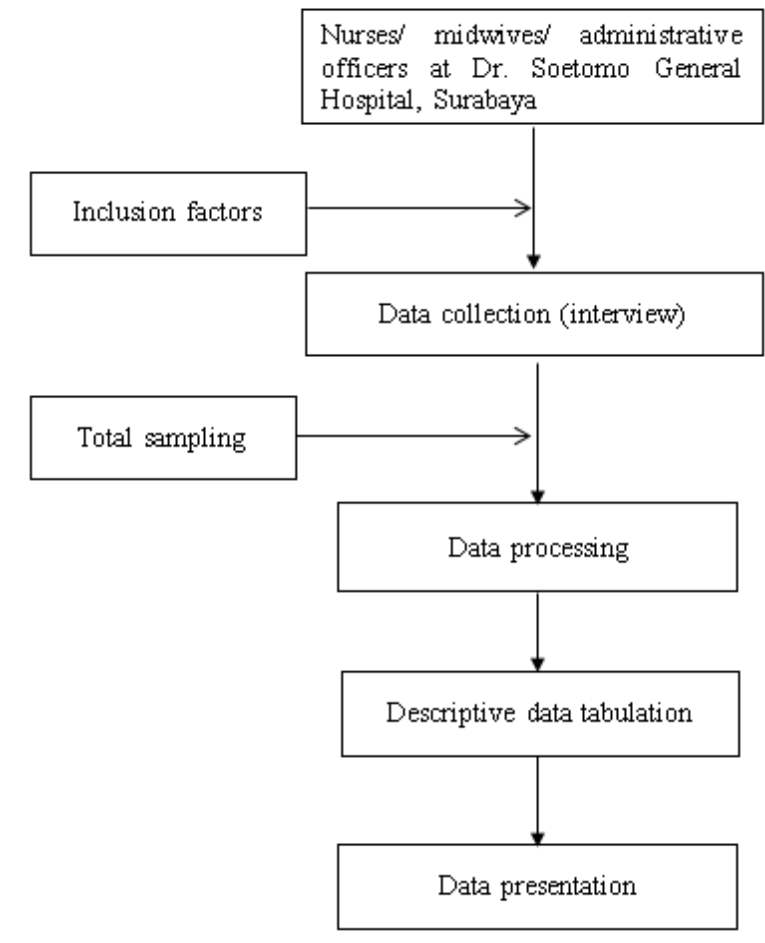

Figure 1. Research flow

\section{Results}

In this study, the involved participants were divided into two groups. Out of 57 participants, 28 (49.12\%) were included in group with history of rotating night shift work and 29 (50.88\%) in group without history of rotating night shift work. Twenty three participants $(82.1 \%)$ in group with history of rotating night shift have worked for $>20$ years, and in group without history of rotating night shift 16 participants $(55.2 \%)$ have worked for $>20$ years. Length of work employees with rotating night shift was $11-15$ years $(14.3 \%), 15-20$ years $(46.4 \%)$ and $>20$ years (39.3\%). Most of participants (60.7\%) had 21-30 hours night shift per week.

The characteristics of this research sample can be seen in table 1 . The age of the participants was $53.71+1.58$ years old in the group with night shift work history and $53.83+$ 1.51 years in the group without night shift work history. The relationship between characteristic variables and two sample groups, including susceptibility to stress, caffeine intake intensity, pelvic area surgery, consumption of sedatives for $\geq 2$ years, family planning history, menstrual duration (days), and the number of pads/day. There were statistically significant differences in susceptibility to stress, menstrual duration and the number of pads/day between groups $(p<0.05)$. The frequency for each of these variables is higher in the group with a history of night shift work. ${ }^{5}$

The results of the comparison test for the mean age of menopause between the two groups using the independent t-test showed for the group with history of night shift work was $49+1.56$ years and $50.45+1.06$ years for the group without history of night shift work (a difference of 1.45 years). This 
difference was statistically and clinically significant $(\mathrm{p}=0.000$ and $95 \%$ CI -2.154 to -0.7425 ) (Table 2).

Table 1 shows that in this study there are 21 children aged $>5$ years old and 24 children aged $\leq 5$ years old with average age between 3-5 years old. There are 26 male children and 19 female children. There are only six children in the high risk group from a total of 45 children. 28 children have normal nutritional status, one child obesity, and 16 underweight $(2$ thin, 12 very thin). Sample that experienced remission are 38 children and 7 children not experienced remission.

In table 2 presented cross data which shows the relationship between nutritional status and the response of induction phase therapy. It is seen that patients with acute lymphoblastic leukemia who have the nutritional status of obesity were in remission as many as one children; patients with normal nutrition who did not experience remission as many as 5 children and were in remission as many as 20 children; patients with underweight nutritional status that is not in remission two children and were experienced remission were 16 children; as well as the nutritional status of patients with malnutrition which did not experience remission as much as one person.

From the data processing indicates that there is no correlation between the nutritional status of children with acute lymphoblastic leukemia with the outcome of induction phase $(p=0.798)$.

Table 1. Characteristics of research subjects

\section{Group}

Characteristic

With history of night shift work $\mathrm{n}=28$

Age (years)

$53.71+1.58$

Menopausal age (years)

$49.0+1.56$

Without history of night shift work $\mathrm{n}=29$

p-value of Chi-square test

Ethnic

\begin{tabular}{|c|c|c|c|}
\hline Javanese & $26(92.86 \%)$ & $28(96.55 \%)$ & \\
\hline Madura & $2(7.14 \%)$ & $1(3.45 \%)$ & \\
\hline \multicolumn{4}{|l|}{ Origin } \\
\hline Surabaya & $14(50.00 \%)$ & $14(48.28 \%)$ & 0.653 \\
\hline Banyuwangi & $2(7.14 \%)$ & $3(10.34 \%)$ & \\
\hline Blitar & $1(3.57 \%)$ & $0(0.00 \%)$ & \\
\hline Gresik & $4(14.30 \%)$ & $3(10.34 \%)$ & \\
\hline Jember & $0(0.00 \%)$ & $1(3.45 \%)$ & \\
\hline Madiun & $1(3.57 \%)$ & $2(6.90 \%)$ & \\
\hline Madura & $2(7.14 \%)$ & $1(3.45 \%)$ & \\
\hline Malang & $0(0.00 \%)$ & $2(6.90 \%)$ & \\
\hline Mojokerto & $2(7.14 \%)$ & $0(0.00 \%)$ & \\
\hline Sidoarjo & $2(7.14 \%)$ & $3(10.34 \%)$ & \\
\hline \multicolumn{4}{|c|}{ Place of residence/address } \\
\hline Surabaya & $22(78.6 \%)$ & $22(75.8 \%)$ & 0.355 \\
\hline Gresik & $0(0.00 \%)$ & $2(6.9 \%)$ & \\
\hline Sidoarjo & $6(21.4 \%)$ & $5(17.2 \%)$ & \\
\hline \multicolumn{4}{|l|}{ BMI } \\
\hline Underweight & $0(0.00 \%)$ & $0(0.00 \%)$ & 0.261 \\
\hline Normal & $12(42.86 \%)$ & $17(58.62 \%)$ & \\
\hline Overweight & $12(42.86 \%)$ & $11(37.93 \%)$ & \\
\hline Obese & $4(14.28 \%)$ & $1(3.45 \%)$ & \\
\hline \multicolumn{4}{|l|}{ Marital status } \\
\hline Single & $1(3.6 \%)$ & $0(0.0 \%)$ & 0.305 \\
\hline Married & $27(96.4 \%)$ & $29(100.0 \%)$ & \\
\hline \multicolumn{4}{|l|}{ Occupation } \\
\hline Midwife & $16(57.1 \%)$ & $0(0.0 \%)$ & 0.000 \\
\hline Nurse & $12(42.9 \%)$ & $0(0.0 \%)$ & \\
\hline Administration officer & $0(0.00 \%)$ & $29(100 \%)$ & \\
\hline \multicolumn{4}{|l|}{ Length of work (years) } \\
\hline $11-20$ & $5(17.9 \%)$ & $13(44.8 \%)$ & 0.029 \\
\hline
\end{tabular}




\begin{tabular}{|c|c|c|c|}
\hline$>20$ & $23(82.1 \%)$ & $16(55.2 \%)$ & \\
\hline \multicolumn{4}{|c|}{$\begin{array}{l}\text { Length of work with night } \\
\text { shift (years) }\end{array}$} \\
\hline Never & $0(0.00 \%)$ & $29(100 \%)$ & 0.000 \\
\hline $11-15$ & $4(14.3 \%)$ & $0(0.00 \%)$ & \\
\hline $15-20$ & $13(46.4 \%)$ & $0(0.00 \%)$ & \\
\hline$>20$ & $11(39.3 \%)$ & $(0.00 \%)$ & \\
\hline \multicolumn{4}{|c|}{$\begin{array}{l}\text { Length of night shift work } \\
\text { (hours/week) }\end{array}$} \\
\hline Never & $0(0.0 \%)$ & $29(100 \%)$ & 0.000 \\
\hline $11-20$ & $8(28.6 \%)$ & $0(0.0 \%)$ & \\
\hline $21-30$ & $17(60.7 \%)$ & $0(0.0 \%)$ & \\
\hline$>30$ & $3(10.7 \%)$ & $(0.0 \%)$ & \\
\hline \multicolumn{4}{|c|}{ Easily stressed } \\
\hline Yes & $22(78.6 \%)$ & $8(27.6 \%)$ & 0.000 \\
\hline No & $6(21.4 \%)$ & $21(72.4 \%)$ & \\
\hline \multicolumn{4}{|c|}{ Active smoker } \\
\hline Yes & $0(0.0 \%)$ & $0(0.0 \%)$ & - \\
\hline No & $28(100.0 \%)$ & $29(100.0 \%)$ & \\
\hline \multicolumn{4}{|c|}{ Passive smoker } \\
\hline Yes & $18(64.3 \%)$ & $19(65.5 \%)$ & 0.922 \\
\hline No & $10(35.7 \%)$ & $10(34.5 \%)$ & \\
\hline \multicolumn{4}{|c|}{ Caffeine drinks } \\
\hline Yes & $10(35.7 \%)$ & $6(20.7 \%)$ & 0.207 \\
\hline No & $18(64.3 \%)$ & $23(79.3 \%)$ & \\
\hline \multicolumn{4}{|c|}{ Intensity of caffeine } \\
\hline Never & $18(64.3 \%)$ & $23(79.3 \%)$ & 0.030 \\
\hline Every day & $6(21.4 \%)$ & $0(0.0 \%)$ & \\
\hline$<3 \mathrm{x} /$ week & $4(14.3 \%)$ & $6(20.7 \%)$ & \\
\hline \multicolumn{4}{|l|}{ Insomnia } \\
\hline Yes & $6(21.4 \%)$ & $7(24.1 \%)$ & 0.807 \\
\hline No & $22(78.6 \%)$ & $22(75.9 \%)$ & \\
\hline \multicolumn{4}{|c|}{ Length of insomnia (years) } \\
\hline Never & $22(78.6 \%)$ & $22(75.9 \%)$ & 0.263 \\
\hline$<1$ & $2(7.1 \%)$ & $6(20.7 \%)$ & \\
\hline $1-10$ & $3(10.7 \%)$ & $1(3.4 \%)$ & \\
\hline $11-20$ & $1(3.6 \%)$ & $0(0.0 \%)$ & \\
\hline \multicolumn{4}{|c|}{ Alcoholic beverages } \\
\hline Yes & $0(0.0 \%)$ & $0(0.0 \%)$ & - \\
\hline No & $28(100.0 \%)$ & $29(100.0 \%)$ & \\
\hline \multicolumn{4}{|l|}{ Soft drinks } \\
\hline Yes & $5(17.9 \%)$ & $5(17.2 \%)$ & 0.951 \\
\hline No & $23(82.1 \%)$ & $24(82.8 \%)$ & \\
\hline \multicolumn{4}{|c|}{ Intensity of soft drinks } \\
\hline Never & $23(82.1 \%)$ & $24(82.8 \%)$ & 0.286 \\
\hline Every day & $2(7.1 \%)$ & $0(0.0 \%)$ & \\
\hline$<2 \mathrm{x} /$ month & $3(10.7 \%)$ & $5(17.2 \%)$ & \\
\hline \multicolumn{4}{|c|}{$\begin{array}{l}\text { Pelvic area surgery (other } \\
\text { than ovarian surgery) }\end{array}$} \\
\hline Yes & $11(39.3 \%)$ & $0(0.0 \%)$ & 0.000 \\
\hline
\end{tabular}




\begin{tabular}{|c|c|c|c|}
\hline No & $17(60.7 \%)$ & $29(100.0 \%)$ & \\
\hline \multicolumn{4}{|c|}{ Diabetes mellitus } \\
\hline Yes & $5(17.9 \%)$ & $5(17.2 \%)$ & 0.951 \\
\hline No & $23(82.1 \%)$ & $24(82.8 \%)$ & \\
\hline \multicolumn{4}{|c|}{ Thyroid disease } \\
\hline Yes & $0(0.0 \%)$ & $0(0.0 \%)$ & - \\
\hline No & $28(100 \%)$ & $29(100 \%)$ & \\
\hline \multicolumn{4}{|c|}{$\begin{array}{l}\text { Consumption of sedatives } \geq \\
2 \text { years }\end{array}$} \\
\hline Yes & $4(14.2 \%)$ & $0(0.0 \%)$ & 0.035 \\
\hline No & $24(85.7 \%)$ & $29(100.0 \%)$ & \\
\hline \multicolumn{4}{|c|}{ With children } \\
\hline Yes & $27(96.4 \%)$ & $29(100.0 \%)$ & 0.305 \\
\hline No & $1(3.6 \%)$ & $0(0.0 \%)$ & \\
\hline \multicolumn{4}{|c|}{ Youngest child's age (years) } \\
\hline$<10$ & $0(0.0 \%)$ & $0(0.0 \%)$ & - \\
\hline$\geq 10$ & $27(96.4 \%)$ & $29(100.0 \%)$ & \\
\hline \multicolumn{4}{|c|}{ History of CS } \\
\hline Yes & $9(32.1 \%)$ & $6(20.7 \%)$ & 0.326 \\
\hline No & $19(67.9 \%)$ & $23(79.3 \%)$ & \\
\hline \multicolumn{4}{|c|}{ Frequency of CS } \\
\hline Never & $20(71.4 \%)$ & $23(79.3 \%)$ & 0.708 \\
\hline$<2 \mathrm{x}$ & $3(10.7 \%)$ & $3(10.3 \%)$ & \\
\hline$\geq 2 x$ & $5(17.9 \%)$ & $3(10.3 \%)$ & \\
\hline \multicolumn{4}{|c|}{ History of abortion } \\
\hline Yes & $6(21.4 \%)$ & $8(27.6 \%)$ & 0.589 \\
\hline No & $22(78.6 \%)$ & $21(72.4 \%)$ & \\
\hline \multicolumn{4}{|c|}{$\begin{array}{l}\text { Gestational age at abortion } \\
\text { (weeks) }\end{array}$} \\
\hline Never & $22(78.6 \%)$ & $20(69.0 \%)$ & 0.135 \\
\hline$<12$ & $4(14.3 \%)$ & $9(31.0 \%)$ & \\
\hline$>12-16$ & $2(7.1 \%)$ & $0(0.0 \%)$ & \\
\hline \multicolumn{4}{|c|}{ Frequency of abortion } \\
\hline Never & $22(78.6 \%)$ & $20(69.0 \%)$ & 0.410 \\
\hline$<3 \mathrm{x}$ & $6(21.4 \%)$ & $9(31.0 \%)$ & \\
\hline \multicolumn{4}{|c|}{ History of contraception } \\
\hline Yes & $17(60.7 \%)$ & $10(34.5 \%)$ & 0.047 \\
\hline No & $11(39.3 \%)$ & $19(65.5 \%)$ & \\
\hline \multicolumn{4}{|c|}{ Types of contraception } \\
\hline Never & $11(39.3 \%)$ & $19(65.5 \%)$ & 0.211 \\
\hline IUD/spiral & $10(35.7 \%)$ & $7(24.1 \%)$ & \\
\hline Implant & $3(10.7 \%)$ & $2(6.9 \%)$ & \\
\hline Pill & $1(3.6 \%)$ & $1(3.4 \%)$ & \\
\hline Sterilization & $3(10.7 \%)$ & $0(0.0 \%)$ & \\
\hline \multicolumn{4}{|c|}{ Years of contraception } \\
\hline Never & $11(39.3 \%)$ & $19(65.5 \%)$ & 0.163 \\
\hline$<5$ & $1(3.6 \%)$ & $2(6.9 \%)$ & \\
\hline $5-10$ & $12(42.9 \%)$ & $6(60.7 \%)$ & \\
\hline $11-15$ & $4(14.3 \%)$ & $2(6.9 \%)$ & \\
\hline
\end{tabular}




\begin{tabular}{|c|c|c|c|}
\hline \multicolumn{4}{|c|}{ Last contraception (years) } \\
\hline Never & $11(39.3 \%)$ & $19(65.5 \%)$ & 0.117 \\
\hline$<5$ & $3(10.7 \%)$ & $0(0.0 \%)$ & \\
\hline $5-10$ & $9(32.1 \%)$ & $8(27.6 \%)$ & \\
\hline $11-15$ & $3(10.7 \%)$ & $2(6.9 \%)$ & \\
\hline $16-20$ & $2(7.1 \%)$ & $0(0.0 \%)$ & \\
\hline \multicolumn{4}{|c|}{ Menarche age (years) } \\
\hline$\leq 10$ & $6(21.4 \%)$ & $12(41.4 \%)$ & 0.269 \\
\hline $11-13$ & $17(60.7 \%)$ & $13(44.8 \%)$ & \\
\hline $14-16$ & $5(17.9 \%)$ & $4(13.8 \%)$ & \\
\hline \multicolumn{4}{|c|}{ Regular menstruation } \\
\hline Yes & $20(71.4 \%)$ & $23(79.3 \%)$ & 0.490 \\
\hline No & $8(28.6 \%)$ & $6(20.7 \%)$ & \\
\hline \multicolumn{4}{|c|}{$\begin{array}{l}\text { Onset of irregular } \\
\text { menstruation }\end{array}$} \\
\hline Never & $19(67.9 \%)$ & $23(79.3 \%)$ & 0.438 \\
\hline Before marriage & $1(3.6 \%)$ & $0(0.0 \%)$ & \\
\hline After marriage & $8(28.6 \%)$ & $6(20.7 \%)$ & \\
\hline \multicolumn{4}{|c|}{ Longer/shorter if irregular } \\
\hline Never & $20(71.4 \%)$ & $23(79.3 \%)$ & 0.708 \\
\hline Longer & $3(10.7 \%)$ & $3(10.3 \%)$ & \\
\hline Shorter & $5(17.9 \%)$ & $3(10.3 \%)$ & \\
\hline \multicolumn{4}{|c|}{$\begin{array}{l}\begin{array}{l}\text { Length of menstruation } \\
\text { (days) }\end{array} \\
\end{array}$} \\
\hline $3-4$ & $4(14.3 \%)$ & $12(41.4 \%)$ & 0.010 \\
\hline $4-5$ & $8(28.6 \%)$ & $12(41.4 \%)$ & \\
\hline $6-7$ & $13(46.4 \%)$ & $5(17.2 \%)$ & \\
\hline$>8$ & $3(10.7 \%)$ & $0(0.0 \%)$ & \\
\hline \multicolumn{4}{|c|}{ Number of pads/day } \\
\hline$\leq 3$ & $10(35.7 \%)$ & $18(62.1 \%)$ & 0.047 \\
\hline $4-5$ & $18(64.3 \%)$ & $11(37.9 \%)$ & \\
\hline \multicolumn{4}{|l|}{ Menstrual pain } \\
\hline Yes & $8(28.6 \%)$ & $6(20.7 \%)$ & 0.490 \\
\hline No & $20(71.4 \%)$ & $23(79.3 \%)$ & \\
\hline \multicolumn{4}{|c|}{$\begin{array}{l}\text { Hormonal drugs before } \\
\text { menopause }\end{array}$} \\
\hline Yes & $0(0.0 \%)$ & $0(0.0 \%)$ & - \\
\hline No & $28(100 \%)$ & $29(100 \%)$ & \\
\hline
\end{tabular}

Table 2. The results of the comparison of menopausal ages between groups with history of night shift work and without history of night shift work

\begin{tabular}{|c|c|c|c|c|c|c|c|}
\hline & \multicolumn{4}{|c|}{ Groups } & \multirow{3}{*}{$\begin{array}{c}\text { Mean } \\
\text { difference }\end{array}$} & \multirow{3}{*}{$\begin{array}{c}\text { CI 95\% } \\
\text { (Lower - upper) }\end{array}$} & \multirow{3}{*}{$\begin{array}{c}\text { p-value of } \\
\text { Chi-square } \\
\text { test }\end{array}$} \\
\hline & \multicolumn{2}{|c|}{$\begin{array}{l}\text { With history of night } \\
\text { shift work }(n=28)\end{array}$} & \multicolumn{2}{|c|}{$\begin{array}{l}\text { Without history of night } \\
\text { shift work }(n=29)\end{array}$} & & & \\
\hline & Mean & $\pm \mathrm{SD}$ & Mean & $\pm \mathrm{SD}$ & & & \\
\hline $\begin{array}{l}\text { Menopausal } \\
\text { age (years) }\end{array}$ & 49.0 & 1.56 & 50.45 & 1.06 & -1.44828 & $\begin{array}{l}(-2.154 \text { up to } \\
-0.7425)\end{array}$ & 0.000 \\
\hline
\end{tabular}




\section{Discussion}

Night shift work has long been associated with a number of health problems, such as headache, fatigue and gastrointestinal disturbance; and some aspect of reproductive health (e.g., preterm labour, spontaneous abortion), and increase risk of earlier menopause.6-9 In accordance with the objective of this study, which is to determine whether there is a relationship between night shift work and menopausal age, a statistical test was performed using the independent t-test on these two variables. It was found that there was a relationship between the onset age of menopause and the night shift work factor among nurses/ midwives/ administrative officers at Dr. Soetomo General Academic Hospital, Surabaya. These results are consistent with the cohort study of Stock et al., conducted on 80.840 female nurses regarding the age of menopause and history of night shift work. ${ }^{6}$ Women who worked night shifts for 20 months or more than 2 years had a greater risk of early menopause than those who worked without night shift. After 10 years of observation, it was also found that women who worked more than 20 years on night shifts would experience menopause earlier. The results of the study concluded that premenopausal women who exceed the threshold for night shift work are at risk of experiencing a more rapid onset of menopause, with the most pronounced effect among younger women being at higher risk for both early ovarian failure and earlier menopause. ${ }^{6}$ In that study, it was explained that the assessment can only be done to see the role of circadian excitability through a cascade effect on the central and peripheral targets of the hypothalamus-pituitary-ovarian (HPO) axis (including nocturnal melatonin suppression). ${ }^{10}$ Additionally, many research have studied how earlier menopause can occur in workers on night shifts. This is due to a disturbance in the body's circadian system in which workers with night shift will experience homeostatic disturbances in the sleep/wake cycle which will affect the pulsation of LH secretion and in turn can cause both menstrual disorders and menopause that occur at an earlier age. ${ }^{11-13}$ In addition, workers with night shifts are also more exposed to light than those who sleep with normal sleep time (at night). Exposure to light causes suppression of the melatonin hormone which can cause various disorders in the body including the reproductive system. ${ }^{14}$ The effect of the melatonin hormone is directly related to the ovaries. Melatonin act as an antioxidant and anti-apoptosis (melatonin can capture free radicals produced from the process of ovulation) in ovaries..$^{15}$

Many studies have shown that follicular cell death during atresia occurs due to apoptosis. Many women with ovarian failure such as premature ovarian failure, oophoritis, or unknown infertility, are suspected having this apoptosis in ovarian follicular cells. Apoptosis occurs when mitochondrial membrane become permeable to release pro-apoptotic factors. Melatonin can directly inhibit the permeability of the transition pores, hence melatonin have an antiapoptotic effect. ${ }^{16,17}$ The higher levels of melatonin in follicular fluid may be diminished in women who work frequent night shifts due to compromised nocturnal pineal production, exacerbating follicle depletion with sufficient night work exposure. ${ }^{18,19}$

The effect of melatonin as anti-apoptosis is closely related to its function as an antioxidant that inhibit free radicals such as Reactive Nitrogen Species (RNS) and Reactive Oxygen Species (ROS). The ability melatonin inhibit free radicals is very important because ovulation stimulates a local inflammatory response that causes inflammatory cells such as macrophages and neutrophils produce free radicals. Free radicals will eventually cause apoptosis in ovarian cells. High levels of melatonin in ovarian follicles make ovarian cells develop and mature. ${ }^{18-20}$ Therefore, if melatonin levels are too low (as can be the case with night shift workers), follicular cell death can increase and this results in a decreased number of follicles that have the potential to ovulate, which in turn can cause a person to experience menopause at an earlier age. Psychological stress has been associated with higher levels of oxidative stress and markers of declining ovarian reserve in premenopausal women. ${ }^{21}$

Study results can only be generalized to populations that have the same characteristics as the sample of this study. This is because there are restrictions, i.e. inclusion criteria (menopausal women) and exclusion criteria (women with a history of ovarian surgery, chemotherapy and radiation, and autoimmune diseases), so there may be limitations in generalizing the study results.

This study can be used as a preliminary study for other researchers who will discuss or analyze more deeply the effect of night shift work with earlier menopausal age. For future researchers it is recommended to conduct research with a larger sample population, for example for all workers of Dr. Soetomo General Academic Hospital, Surabaya regardless of their status of a nurse/ midwife/ administrative officer. Likewise, other factors that can affect the early age of menopause can also be considered to be studied in more depth and detail in order to reduce the bias factor of the research results.

Other variables or parameters, especially those that can be measured such as melatonin levels, can also be included to find out how hormone levels between those with night shift work history is different from those without night shift work history, where it is expected that the hormone levels will be lower in those with night shift work. Because working night shifts cannot be avoided by medical personnel or those who work in hospitals, it is expected that the results of this study can make these workers more healthy and vigilant in carrying out their work, considering that there is a considerable risk of getting health problems as well as negligence in work caused by fatigue due to night shift work.

\section{Conclusion}

Our study concluded that there was correlation between night shift with the onset of menopausal age. Women who had night shift work have 1.45 years earlier menopausal onset than those who never have night shift work at Dr. Soetomo General Academic Hospital, Surabaya.

\section{Acknowledgement}

We thanks to all the staff Department Obstetric and Gynecology, Dr. Soetomo General Academic HospitalUniversitas Airlangga, Faculty of Medicine who contributed provide inputs for this research. Also to all 
the medical workers who involved as participant in this research.

\section{Conflict of Interest}

The author stated there is no conflict of interest

\section{References}

1. Mulyani NS. Menopause: Akhir Siklus Menstruasi pada Wanita di Usia Pertengahan. Yogyakarta: Nuha Medika, 2001.

2. Harlow SD, Gass M, Hall JE, et al. Executive Summary of the Stages of Reproductive Aging Workshop + 10: Addressing the Unfinished Agenda of Staging Reproductive Aging. Menopause 2012; 19: 387395.

3. Ang $\mathrm{S}$ Bin, How $\mathrm{CH}$. Menopause: An Important Milestone in Women's Health. Singapore Med J 2013; 54: 60-63.

4. Taylor HS, Pal L, Seli E. Menopause and the Perimenopausal Transition. In: Speroff's Clinical Gynecologic Endocrinology and Infertility. Philadelphia, 2020.

5. Ceylan B, Özerdoğan N. Factors Affecting Age of Onset of Menopause and Determination of Quality of Life in Menopause. Turkish J Obstet Gynecol 2015; 12: 43-49.

6. Stock D, Knight JA, Raboud J, et al. Rotating Night Shift Work and Menopausal Age. Hum Reprod 2019; 34: 539-548.

7. Lawson CC, Whelan EA, Lividoti Hibert EN, et al. Rotating Shift Work and Menstrual Cycle Characteristics. Epidemiology 2011; 22: 305-312.

8. Meczekalski B, Podfigurna-Stopa A, Genazzani AR. Hypoestrogenism in Young Women and Its Influence on Bone Mass Density. Gynecol Endocrinol Off J Int Soc Gynecol Endocrinol 2010; 26: 652-657.

9. Bonzini M, Coggon D, Palmer KT. Risk of Prematurity, Low Birthweight and Pre-Eclampsia in Relation to Working Hours and Physical Activities: A Systematic Review. Occup Environ Med 2007; 64: $228-243$.
10. Baker FC, Driver HS. Circadian Rhythms, Sleep, and the Menstrual Cycle. Sleep Med 2007; 8: 613-622.

11. Cipolla-Neto J, Amaral FG do. Melatonin as a Hormone: New Physiological and Clinical Insights. Endocr Rev 2018; 39: 990-1028.

12. Chu A, Zhu L, Blum ID, et al. Global but Not Gonadotrope-Specific Disruption of Bmall Abolishes the Luteinizing Hormone Surge without Affecting Ovulation. Endocrinology 2013; 154: 2924-2935.

13. Tähkämö L, Partonen T, Pesonen A-K. Systematic Review of Light Exposure Impact on Human Circadian Rhythm. Chronobiol Int 2019; 36: $151-170$.

14. Tamura H, Nakamura Y, Korkmaz A, et al. Melatonin and the Ovary: Physiological and Pathophysiological Implications. Fertil Steril 2009; 92: 328-343.

15. Radogna F, Cristofanon S, Paternoster L, et al. Melatonin Antagonizes the Intrinsic Pathway of Apoptosis Via Mitochondrial Targeting of Bcl-2. J Pineal Res 2008; 44: 316-325.

16. Han Y, Zhang S, Wang $\mathrm{X}$, et al. Inhibition of Mitochondria Responsible for the Anti-Apoptotic Effects of Melatonin during Ischemia-Reperfusion. J Zhejiang Univ Sci B 2006; 7: 142-147.

17. Adriaens I, Jacquet P, Cortvrindt R, et al. Melatonin has DoseDependent Effects on Folliculogenesis, Oocyte Maturation Capacity and Steroidogenesis. Toxicology 2006; 228: 333-343.

18. Tamura H, Takasaki A, Taketani T, et al. The Role of Melatonin as an Antioxidant in the Follicle. J Ovarian Res 2012; 5: 5.

19. Tamura H, Kawamoto M, Sato S, et al. Long-Term Melatonin Treatment Delays Ovarian Aging. J Pineal Res; 62. Epub ahead of print March 2017. DOI: 10.1111/jpi.12381.

20. Tamura H, Takasaki A, Taketani T, et al. Melatonin as a Free Radical Scavenger in the Ovarian Follicle. Endocr J 2013; 60: 1-13.

21. Bleil ME, Adler NE, Pasch LA, et al. Depressive Symptomatology, Psychological Stress, and Ovarian Reserve: A Role for Psychological Factors in Ovarian Aging? Menopause 2012; 19: 1176-1185. 